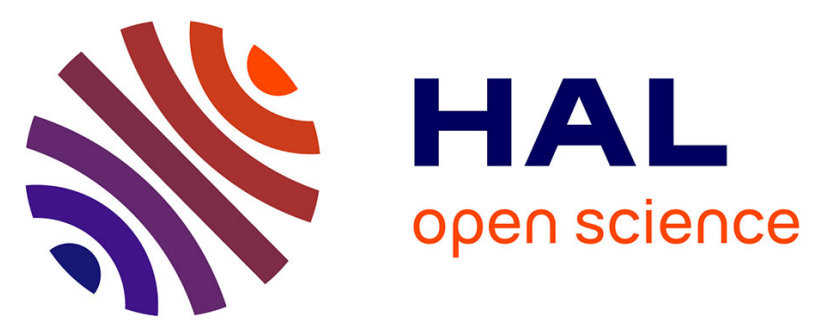

\title{
Complementarities in organizational innovation practices: evidence from French industrial firms Complementarities in organizational innovation practices: evidence from French industrial firms
}

Caroline Mothe, Thu Nguyen Nguyen Thi, Phu Nguyen-Van

\section{To cite this version:}

Caroline Mothe, Thu Nguyen Nguyen Thi, Phu Nguyen-Van. Complementarities in organizational innovation practices: evidence from French industrial firms Complementarities in organizational innovation practices: evidence from French industrial firms. Economics of Innovation and New Technology, 2015, 24 (6), pp.569-595. 10.1080/10438599.2014.949416 . hal-01293802

HAL Id: hal-01293802

https://hal.univ-grenoble-alpes.fr/hal-01293802

Submitted on 25 Mar 2016

HAL is a multi-disciplinary open access archive for the deposit and dissemination of scientific research documents, whether they are published or not. The documents may come from teaching and research institutions in France or abroad, or from public or private research centers.
L'archive ouverte pluridisciplinaire HAL, est destinée au dépôt et à la diffusion de documents scientifiques de niveau recherche, publiés ou non, émanant des établissements d'enseignement et de recherche français ou étrangers, des laboratoires publics ou privés. 
Complementarities in organizational innovation practices: evidence from French industrial firms*

Caroline Mothe ${ }^{\S}$

IREGE, University of Savoie

B.P. 80439, 74944 Annecy-le-Vieux, France

Email :Caroline.Mothe@univ-savoie.fr

Uyen T. Nguyen-Thi

CEPS/INSTEAD

3, Avenue de la Fonte, 4364 Esch-sur-Alzette, Luxembourg

Email : thithucuyen.nguyen@ceps.lu

Phu Nguyen-Van

BETA-CNRS, University of Strasbourg

61 avenue de la Foret Noire, 67085 Strasbourg Cedex, France

Email:nguyen-van@unistra.fr

\footnotetext{
* The authors thank the editor and three anonymous referees for their valuable remarks and suggestions. The usual caveat applies.

${ }^{\S}$ Corresponding author. Caroline Mothe, IREGE Institute, IAE Savoie Mont Blanc, B.P. 80439, 74944 Annecyle-Vieux, Tel. : (0033) 04500924 40, E-mail: caroline.mothe@univ-savoie.fr
} 


\title{
Complementarities in organizational innovation practices: evidence from French industrial firms
}

\begin{abstract}
Organizational innovation favours technological innovation. Yet the question of which organizational practices should be combined - that is, their compatibility-remains unanswered. This empirical investigation of patterns of complementarity considers three organizational practices: business practices, workplace organization, and external relations. Firm-level data drawn from the 2008 French Community Innovation Survey and supermodularity tests confirm the crucial role of organizational innovation in increasing firms' innovation. The pattern of complementarity among organizational practices differs according to the type of innovation (i.e., product or process), as well as the type of measure used to assess technological innovation performance. These results highlight the complexity of managing organizational practices to encourage firm innovation.
\end{abstract}

Keywords: Complementarity, Organizational innovation, Supermodularity, Technological innovation 


\section{Introduction}

The importance of managing different types of resources has long been highlighted, such as by the resource-based view of the firm and evolutionary economic theory (e.g., Penrose 1959; Nelson and Winter 1982; Teece 1988). Firms' innovation capabilities depend on not only their internal competencies (e.g., R\&D activities) but also their ability to develop organizational strategies for managing innovation processes. This idea, developed by Milgrom and Roberts (1990, 1995) on the basis of Teece's (1986) notion of complementary assets, has prompted significant economic and management research into complementarity and its role in organizational designs (Ennen and Richter 2010). In a general sense, complementarity refers to beneficial interplays of the elements of a system, such that doing more of one thing increases the returns earned from doing more of the other (Milgrom and Roberts 1995).

In this article, we consider the relationship between organizational and technological innovation by focusing on complementarities among organizational innovation practices and their impact on technological innovation. Prior research offers some information about the relationships of technological and non-technological innovation, though it remains a "very complex and under-investigated topic" (Evangelista and Vezzani 2010,1262). Evangelista and Vezzani (2010) show that broadening the scope of innovation research beyond technological domains is crucial to understanding economic performance, because organizational innovation modes also have substantial impacts. The adoption of a more systemic approach to innovation — combining product, process, and organizational change - is what gives firms a true competitive advantage. Battisti and Stoneman (2010), exploring the simultaneous use of a wide set of innovations by 16,383 British firms between 2002 and 2004, further argue that the range of innovations can be summarised using two factorsorganizational and technological — that are complements but not substitutes for each other. Most studies thus analyse potential complementarities across various innovation types and their effects on firm performance.

Relatively fewer studies deal with the complementarities among organizational innovation practices and their effects on technological innovation. Khanagha and colleagues (2013) reveal, with a study of a large telecommunication firm, how organizational innovation (i.e., a novel structural approach) can overcome rigidities in existing routines and foster an environment that allows for the adoption of an emerging cloud technology. We go one step further by investigating whether organizational innovation practices are complementary with technological innovation. 
That is, recent studies suggest that complementarities exist across various types of organizational innovation practices, such as workplace organization (Ichniowski, Shaw, and Prennushi 1997; Cappelli and Newmark 2001), human resource management (Laursen and Mahnke 2001), and external relations (Arora and Gambardella 1990). But these alternative organizational practices have not been studied in combination, with one exception: Cozzarin and Percival (2006) consider the complementarities of organizational practices with novel strategies. We extend these prior contributions by investigating multiple complementarities across three types of organizational practices (business practices, workplace organization, and external relations) and their resultant effect on technological innovation performance. In particular, Cozzarin and Percival (2006) group 16 organizational variables into four factors: hiring focus, research and development, market focus, and reputation focus (which comprises satisfying existing clients, promoting reputation, hiring experienced employees, and training). The authors show that innovation complements many organizational strategies. We take a different perspective and highlight the different complementary effects that arise for product and process innovation, using three measures of technological innovation performance. Furthermore, we apply different dependent and independent variables and a unique database in this study, ${ }^{1}$ to build on the contributions provided by Cozzarin and Percival (2006).

By studying the effect of complementarities among organizational practices on innovation performance, we argue that technological innovation performance can be improved by simultaneously certain types of organizational innovation practices simultaneously. Because complementarities lead to synergies among complementary activities, failing to take them into account may entail a loss in value creation and performance, in that the firm would fail to achieve its full potential.

With these approaches, we contribute to extant literature in several ways. First, we search for complementarities among organizational innovations in terms of business practices, workplace organization, and external relations to determine their effects on product and process innovation performance. Thus we elaborate hypotheses that reflect previous research on organizational innovation practices and diverge from existing empirical studies that tend to adopt an exploratory methodology. Second, we rely on a robust empirical methodology to test for complementarities and compare a correlation/adoption approach with

\footnotetext{
${ }^{1}$ The availability of databases often conditions the choice of variables, which partly explains why so few authors have examined the set of organizational practices we consider. We thank an anonymous reviewer for suggesting this rationale.
} 
performance analysis. Accordingly, we begin this article by highlighting the neglected role of organizational innovation in technological innovation processes. From a review of theoretical research into organizational innovation and complementarities, we elaborate our main research propositions. Next, we describe the French Community Innovation Survey (CIS) from 2008, the variables used, and our method for testing for complementarities. After we present the estimation results, we close with some summary remarks, limitations, and further research directions.

\section{Role of organizational innovation in technological innovation processes}

Organizational innovation is a broad theoretical concept that encompasses strategies, as well as structural and behavioural dimensions. Yet no consensus definition of organizational innovation exists: Some authors include all types of innovation under this heading (e.g., Daft 1978; Kimberly and Evanisko 1981; Damanpour and Evan 1984; Crossan and Apaydin 2010), others use organizational innovation to refer to technological innovation (e.g., Gumusluoğlu and Ilsev 2009), and still others differentiate the two forms (e.g., Baldridge and Burnham 1975; Battisti and Stoneman 2010). The term "management innovation" also reappeared relatively recently (e.g., De Cock and Hipkin, 1997; Birkinshaw, Mol, and Hamel 2008; Mol and Birkinshaw 2012; Khanagha et al. 2013). In the absence of a unified theoretical definition, we adopt the OECD's (2005) version: organizational innovation is “the implementation of a new organizational method in the firm's business practices, knowledge management, workplace organization or external relations that has not been previously used by the firm."2

\section{Relationships between organizational and technological innovations}

Studies of the relationships between organizational and technological innovations often highlight how technological innovation drives organizational changes within the firm (e.g., Khanagha et al. 2013). Thus firms that introduce technological innovation must reorganise their production, workforce, sales, and distribution systems. Another research stream emphasises the inverse relationship, stressing the role of organizational innovation in enhancing flexibility and creativity, which then facilitate technological innovation

\footnotetext{
2 Some studies (e.g., Battisti and Iona 2009; Mol and Birkinshaw 2009) use terms such as "management innovation" or "management practices" to describe aspects similar to those we include within organizational innovation. The diversity in definitions and terminologies likely reflects the underlying database; the UK Innovation Survey for example adopts the wording "management innovation" but uses measures very similar to those applied to measure "organizational innovation" in other innovation surveys.
} 
developments (Mol and Birkinshaw 2012). If organizational (re)structuring leads to structural renewal, it could facilitate other types of innovations (Günday et al. 2011). Although still comparatively scarce, research emphasizing this role of organizational renewal for firms' technological innovations has expanded in recent decades.

For example, Germain (1996) cites organizational structural characteristics as predictors of process innovations in the logistics sector, and Staropoli (1998) emphasise how external relations and networks enhance technological innovation by pharmaceutical firms. Bharadwaj and Menon (2000), using data from 634 firms, affirm that innovation is a function of individual efforts and organizational systems that attempt to facilitate creativity, so successful product innovation depends at least partly on organizational factors. Building on the resource-based view of the firm, Tatikonda and Montoya-Weiss (2001) show that organizational process factors are associated with the achievement of operational outcome targets for new product performance and thus customer satisfaction. Damanpour and Aravind (2006) offer a meta-analysis of research into the effects of organizational determinants on product and process innovations and confirm the positive impact of organizational innovation practices on technological innovation. Noting links across innovation strategies, Schmidt and Rammer (2007) show that the combination of organizational and product innovations exerts positive impacts on firm performance, though no other combinations of technological and non-technological innovations produce higher returns on sales. Günday et al. (2011) similarly establish a positive relationship between organizational innovation and technological innovation (process and product), though without testing for complementarities. According to Foss, Laursen, and Pedersen $(2011,980)$, innovation and marketing literature might claim that firms can improve their innovative activities by tapping users and customers for knowledge, yet "neither literature takes sufficient account of firm organization" or the appropriate internal organization that might support technological innovations. These authors therefore call for the use of new organizational practices, intensive vertical and lateral communication, employee rewards for sharing and acquiring knowledge, and delegation of decision control. In tests with 169 large Danish firms, they confirm that the link from customer knowledge to innovation is completely mediated by organizational practices.

Thus, prior research suggests that firms that dedicate more resources to new organizational forms should be in a better position to use new skills and technologies efficiently. Organizational innovation contributes to creating a suitable environment for process and product innovations, leading us to predict the likely co-occurrence of organizational and technological innovation. That is, we consider the influence of new organizational practices 
on innovation outcomes; we go a step further by addressing the complementarities among such organizational practices.

\section{Empirical studies on organizational innovation practices}

For this study, we investigate three organizational innovation practices: business practices (including knowledge management), workplace organization, and external relations. Previous research has attested to the positive impact of these practices on technological innovation.

Business practices. New business practices include organizational practices, such as business process reengineering, total quality management (TQM), or knowledge management (KM). For De Cock and Hipkin (1997, 659), such management innovations "restore competitiveness and turn traditional, bureaucratic organizations into world-class competitors." With a longitudinal study of photography and paint industries, Benner and Tushman (2002) also show how process management activities (e.g., TQM, Six Sigma) influence the extent to which innovations build on existing firm knowledge. They argue that these widely adopted organizational practices shift the balance of exploitation and exploration, by encouraging a focus on short-term efficiency. The link between TQM and innovation performance thus has led to contradictory results (Singh and Smith 2003). For example, Prajogo and Sohal (2001), using an extensive literature review and discussion, argue in support of both positive and negative outcomes; these same authors also propose that TQM embodies two practice models, mechanistic and organic, with distinct impacts, such that the mechanistic elements of TQM are associated with quality performance and the organic elements relate to innovation performance (Prajogo and Sohal 2004). Galia (2007) also acknowledges the impact of quality management systems on both process and product innovation performance. Perdomo-Ortiz, Gonzalez-Benito, and Galende (2009) provide similar empirical results in a study of 105 Spanish industrial firms, such that only some TQM business practices (e.g., human resource management) have direct, significant impacts on technological innovation.

Empirical studies reveal positive effects of KM practices on product innovation (for a recent review, see Alegre, Sengupta, and Lapiedra, 2013), mainly in line with the knowledgebased theory of the firm, as initially developed by Grant (1996). Knowledge also might be a mediator between human resource practices and innovative activity (Lopez-Cabrales, PerezLuño, and Valle-Cabrera 2009). Palacios, Gil, and Garrigos (2009) further attest to a positive causal relationship between $\mathrm{KM}$ and innovation distinctive competences. Modifying the existing knowledge base (breadth and depth) even could lead to radical innovations (Zhou and 
Li 2012). In general, Alegre and Chiva (2008) underline the importance of learning and knowledge for innovation performance.

Work organization. The European Commission (1997) regards work organization as a key priority for achieving competitiveness, based on improved skills, trust, and quality. According to the OECD (2005), new work practices include decentralized decision making, job rotation, teamwork, employee participation, and shared rewards-generally, new human resource practices. Previous research cites the positive impact of various human resource practices on technological innovation. For example, in their empirical study of German firms, Hempell and Zwick (2008) posit that stronger employee participation increases the probability of product and process innovations in subsequent periods by more than 10 percentage points. Beugelsdijk (2008), with empirical tests of a sample of 988 Dutch firms, emphasises the importance of training and performance-based pay for generating incremental innovations but highlights the impact of the proportion of employees with flexible working hours on radical innovations. Chen and Huang (2009) find, among a sample of 146 firms, that KM capacity mediates between strategic human resource practices and innovation performance. Innovative initiatives thus depend strongly on employees contributing their knowledge, expertise, creativity, and commitment to the process. Training also can encourage innovation, and organizations that provide training benefit from enhanced knowledge, skills, and innovative capability in work tasks (Chen and Huang 2009). With panel data from Canadian firms, Zoghi, Mohr, and Meyer (2010) explore the relationship between the organization of work (i.e., decentralization, information sharing, and incentive pay schemes) and innovation and find a clear positive link.

External relations. Relationships with other firms or public institutions might include alliances, partnerships, outsourcing, or subcontracting. The growing impact of networking on firms' innovation reflects the context established by the emerging, knowledge-based, global economy. Considering the tacit, non-transferable nature of knowledge and the evolving, continuous nature of learning processes, innovative firms need to concentrate on their own specific capabilities but also engage in cooperative arrangements to develop new competencies and expand the firm's know-how. Moreover, they should pursue external relationships to gain access to partners' complementary or synergistic competencies and capitalise on incoming knowledge spillovers (Kogut and Zander 1993). These strategies can avoid the duplication of $R \& D$ efforts, reduce the risks and costs associated with innovation (Sakakibara 1997), and enhance benefits from scale economies (Kogut and Zander 1993). 
Many empirical studies also attest to the positive impact of external collaborations on firms' innovativeness and performance. Firms can reinforce their technological innovation capability by acquiring technologies and then diffusing, assimilating, communicating, and absorbing them into their organizations (Cohen and Levinthal 1990). Teece (2007) ascertains that the ability of a firm to acquire, use, and develop valuable resources and capabilities relates largely to its acquisition of external knowledge and ability to integrate such knowledge with its own. According to Romijn and Albaladejo (2002), interactions with external sources of knowledge provide missing inputs to the leaning process, which the firm cannot provide itself.

Synthesizing these previous studies indicates that implementing new business practices, work organizations, or external relations may improve organizational flexibility and adaptability, which should lead to improved firm efficiency, innovation, and performance. Furthermore, all these organizational practices appear interrelated. For example, some studies include human resource practices, which span both business practices and work organization categories. Michie and Sheehan (2003) reveal the proximity between work organization and external relations, such that industrial relations systems relate to work practices and technological innovation, but labour flexibility practices correlates negatively with innovation. Most studies corroborating the impact of interorganizational relationships and collaboration on innovation emphasise the role of knowledge acquisition, to link external relations to $\mathrm{KM}$ (which can be included in the broader category of business practices). Alternatively, Ettlie and Reza (1992) note that three upstream integrating mechanisms (new hierarchical structure, increased coordination between design and manufacturing, and greater supplier cooperation) enhance the productivity of new manufacturing systems and process innovation; these mechanisms reflect work organization, business practices, and external relations, respectively.

Although the preceding studies generally indicate positive effects of organizational practices on innovation activities and performance, the key remaining question is defining which combinations of various organizational practices have the greatest impact on innovative activity, and whether particular activities act as substitutes or complements. We seek to take the next step by considering the impact of combined (potentially complementary or substitutable) organizational innovations on technological innovation performance. Although many illustrations of complementarity refer to just two activities, "complementarity theory relates not just to pairwise relationships between any two design choices, but among many elements simultaneously" (Ennen and Richter 2010, 213). Therefore, we study 
complementarities among three organizational practices, with innovation performance as the output.

\section{Complementarities among organizational practices}

In our effort to provide further empirical evidence about the complementarities among different organizational practices, we formulate propositions that reflect different pairs of the three organizational practices and their unique influences on technological innovation. In general, we anticipate that firms constantly face the challenge of organizing innovation processes holistically, because their strategic organizational activities are interrelated. If they can exploit the synergies among their existing resources, these firms may generate competitive advantages. The firm's capacity to combine multiple organizational activities simultaneously thus should be a crucial determinant of innovation performance. That is, the capacity can lead to sustained performance differences, because it produces specific, unique skills within the firm that are difficult for others to imitate (Teece, 1986, 1988).

\section{Complementarities in the field of innovation}

The idea of complementary organizational strategies, as first introduced by Learned et al. (1961), suggests simply that strategies can act as complements. The development of this notion by Teece (1986) produced the concept of complementary assets, which in turn have been formalised in complementarity models (Milgrom and Roberts 1995; Topkis 1998). In these models, "Two or more variables are ... complementary if a higher value in any variable increases the marginal returns to higher values in the remaining variables" (Cozzarin and Percival 2006, 201).

Applications of complementarity models are somewhat common in innovative research (Mantovani 2006). Several studies investigate complementarities between internal R\&D expenditures and external technology sourcing (e.g., Belderbos, Carree, and Lokshin 2006; Cassiman and Veugelers 2006; Schmiedeberg 2008) or of process and product innovations (e.g., Mantovani 2006; Miravete and Pernias 2006; Damanpour 2010); others note the various obstacles to innovation (Galia and Legros 2004; Mohnen and Röller 2005). According to our extensive literature review, Cozzarin and Percival (2006) were the first to investigate the complementary effect of a broad, diversified range of organizational practices (including R\&D) on outcomes such as labour productivity, profit, and major innovations. They show that innovation is complementary with many organizational strategies; we pursue a slightly different objective, namely, to elucidate the relationship of various organizational 
innovation practices with technological innovation, such that we clearly differentiate organizational innovation from technological innovation. ${ }^{3}$

\section{Lattices and supermodularity}

Lattice theory is a branch of mathematics related to partially ordered sets; Topkis (1998) and Milgrom and Roberts $(1990,1995)$ apply it to profit maximization problems. The imposed structure allows for the use of discrete variables in the optimization process, which would not be possible with conventional tools. It also provide clear, comparative, static results describing observed changes in firms' organizational strategies (Milgrom and Roberts 1995; Cozzarin and Percival 2006). We use lattice nodes to represent the three organizational innovation practices.

Furthermore, we adopt the concept of supermodularity, which can "formalize the intuitive idea of synergies and systems effects - the idea that 'the whole is more than the sum of its parts"” (Milgrom and Roberts 1995, 184). Implementing one practice thus increases the marginal or incremental return on other practices. A function is supermodular if, for every pair of inputs, the function is supermodular in those inputs (Topkis 1998). These elements enable the creation of supermodular functions to demonstrate the effect described by Milgrom and Roberts (1990, 1995), such that adopting a new organizational practice generates improved firm performance only if it is in line with the firm's other organizational practices. Supermodularities and complementarities (or submodularities) maintained by modern firms should lead to higher profits.

\section{Propositions}

Economic and management theories offer various perspectives on the relationship between business practices and external relations and their synergistic effects on efficiency and performance. Business practices, such as quality, supply chain, knowledge, or lean management, deal with process reengineering and knowledge management across both internal department and external partners. Thus firms can overcome resource constraints and achieve higher innovation performance by acquiring knowledge-based capabilities from external partners. According to the knowledge-based view, firms engaging in external

\footnotetext{
${ }^{3}$ We test not for causality but for correlations across sets of complementary organizational innovation practices with technological innovation performance. We thank an anonymous reviewer for suggesting this clarification.

${ }^{4}$ We thank an anonymous reviewer for reminding us to stress that organizational innovation practices do not necessarily lead to positive performance outcomes. However, because a supermodular function necessarily increases with complementary, we expect that the use of substitutes leads to poorer performance. We leave the construction of lattices for such an analysis to further research.
} 
alliances, R\&D partnerships, outsourcing, and subcontracting do so to acquire new knowledge, optimise and exploit their existing knowledge, and assimilate the knowledge received from external partners (e.g., Vasudeva and Anand 2011). Zhang et al. (2010) confirm that knowledge acquired from alliance partners affects organizational knowledge creation, which leads to innovation performance. When viewed from a transaction cost perspective, firms that are active in their external relations should be better able to organize their own knowledge creation efficiently, on the basis of their existing resources. Existing resources may come from business practices or the work organization (e.g., employee responsibility, teamwork, decentralization). Accordingly, we expect to find a complementary relationship between business practices/work organization on the one hand and external relations on the other. New business practices-especially knowledge management and business reengineering - and workplace reorganizations even may be necessary for a firm to take full advantage of its new external relationships. We thus advance the following propositions:

P1: Business practices and external relations have complementary effects on technological innovation.

P2: Work organization and external relations have complementary effects on technological innovation.

Similarly, some studies focus on the relationships of business practices with workplace organization. Innovation capability depends on the exploitation and exchange of existing knowledge, as well as the ability to organize new knowledge creation through novel business practices. Such knowledge determines firms' capacity to function in economic environments characterised by the emergence of new competitors and rapid changes in consumers' needs and preferences. In such a context, a strategic management system that integrates knowledge management (i.e., business practice) with the work organization should increase firms' efficiency. Furthermore, business practices can be stimulated by work activities, such as learning-by-doing, by-using, by-searching or by-interacting. The simultaneous use of these practices should reinforce firms' efficiency and sustained innovation capacities.

Firms in modern economies often implement sets of workplace practices, which we might label high performance work organization practices, in an effort to facilitate their knowledge integration and information exchange (Grabher 2001). Business practices such as lean production, supply chain management, business reengineering, and quality management instead are depicted as cost management practices, which also are critical for firm success 
(Domanovic and Stojanovic-Aleksic 2010). From a competence theory perspective, the two practices are reinforcing in terms of generating a competitive advantage.

Empirically, Laursen and Mahnke (2001) acknowledge complementarities between $\mathrm{KM}$ and human resource practices that affect product innovation. Some human resource practices constitute business practices (e.g., quality circles), whereas others relate closely to workplace organization (e.g., integration of functions, interdisciplinary workgroups, planned job rotation, delegation of responsibility). Laursen and Foss (2003) confirm such complementarities in human resource practices. Galia (2007), using two French data sets, highlights the complementary nature of work organization and KM, in the sense that teambased work, employees' responsibility systems, training programs, and specific incentives reinforce one another. With U.S. firm-level data, Bresnahan, Brynjolfsson, and Hitt (2002) highlight the complementarity of product and service innovations, information technology, and workplace reorganization, such that new work practices improve firm performance only if they combine with heavy investments in human capital or IT. Kuhn (2010) also notes a complementary relationship, in panel data collected from firms in Switzerland, among decentralized task allocations, decision rights, and up-skilling of employees. Finally, Gebert, Boerner, and Kearney (2010) recommend that firms pursue opposite, complementary strategies, such as combining a particular type of leadership decision making (workplace organization) with KM. In line with these results, we expect a complementary relationship between practices:

P3: Business practices and workplace organization have complementary effects on technological innovation.

\section{Data and variables}

Data

For our empirical analysis, we rely on firm-level data drawn from the French Community Innovation Survey (CIS 2008), which avoids the overly specific conclusions that can arise from analyses based on a smaller country sample. This survey collects data about firms' innovation behaviour, in this case for the three-year period from 2006 to 2008, following the OECD's (2005) recommendations. It provides general information about the firms (e.g., sector of activity, group, number of employees, sales, geographic market), their technological and non-technological innovations, perceptions of the factors that might hamper innovation activities, and subjective evaluations of innovation outcomes. The data set also indicates sources of information and various $R \& D$ cooperation types for innovation. For this 
study, we included firms with at least 20 employees that operated in the manufacturing sector. The resulting large sample of 2,673 firms helps ensure the robustness of our analysis.

\section{Variables}

This study relies on three dependent variables. Product innovation performance is the percentage of total turnover from product innovations that are new to the firm (Mohnen and Röller 2005; Cassiman and Veugelers 2006). The propensity to innovate in products is a binary variable that indicates whether the firm introduced product innovations or not. Finally, propensity to innovate in processes indicates if the firm introduced new or improved productions processes, distribution methods, or offering support (see Appendix A for the variable definitions).

The CIS we consider provides data about the organizational innovations implemented by firms during 2006-2008. It categorises three practices of organizational innovation: (1) new business practices for organizing work and procedures (e.g., supply chain management, knowledge management, business reengineering, quality management, lean production, education/training systems), (2) new workplace organization methods (new employee responsibility systems, teamwork, decentralization, integration or de-integration of departments), and (3) new methods of organizing external relations (alliances, partnerships, outsourcing, subcontracting). Three binary variables reflect each of these practices. ${ }^{5}$

In Table 1, which reports the distribution of the state variables, we observe that $38.8 \%$ of the sample (1,037 of 2,673 firms) does not implement any of these organizational practices, whereas 503 firms (18.82\%) implement all of them simultaneously. A large group of firms introduce business practices and workplace organization together (543 firms, 20.31\%). From Table 1, we also recognise that the most widely adopted single organizational practice, without being combined with other practices, is business practices: $9.88 \%$ of firms introduce them. In contrast, only $2.06 \%$ of firms bring in external relations separately from any other practice.

\section{INSERT TABLE 1 ABOUT HERE -}

Because we include several combinations of organizational practices, each reflecting different aspects of organizational implementation, we used two empirical methodologies in our analyses to evaluate their complementarity and impact on the technological innovation process. In addition, we included several technological innovation determinants in our model. For $R \& D$ intensity, we took the sum of expenditures on intramural (in-house) $R \& D$ and extramural R\&D in 2008, divided by total turnover in 2008. In addition, our study data

\footnotetext{
${ }^{5}$ Unconditional binary correlations between organizational practices appear in Appendix C.
} 
suggest the different motivations for innovation, in that survey respondents rated the importance of product or process innovation on a scale from 0 (unimportant) to 3 (crucial). Similar to Belderbos, Carree, and Lokshin (2006), we generated a cost-push variable by summing the scores of cost-related objectives, such as improved flexibility, increased capacity of production, or reduced labour costs, materials, or energy. We rescaled this score to a number between 0 and 1 . The demand-pull variable is similar, summing the scores of demand-related objectives such as an increased range of products, increased market share, or improved product quality, and then rescaled between 0 and 1 .

Four dummy variables reveal the information sources: (1) internal, such as other firms belonging to the same group; (2) institutional, which reflects a composite measure of information from universities or other higher education institutions, government, consultants, commercial labs, private R\&D institutes, or public research institutes; (3) market, including suppliers, clients, customers, competitors, or other firms in the same sector; and (4) other sources, including conferences, meetings, or other firms.

Finally, we included several traditional control variables. Firm size is the natural logarithm of the number of employees. We introduced a dummy variable for group belonging, equal to 1 if the firm belongs to a group and 0 otherwise. Four sectors of activities were included, according to a two-digit NACE classification of manufacturing industries: (1) hightech, (2) medium high-tech, (3) medium low-tech, and (4) low-tech (which serves as the reference category).

\section{Methodology}

To test for complementarities, we used two extant approaches (Athey and Stern 1998). The first relies on an analysis of the correlation of various organizational practices, conditional on a common set of exogenous variables. This adoption-focused correlation approach requires information about the choice variables, namely, various organizational practices, but no data about the objective function (Mohnen and Röller 2005). The second approach is a performance-based analysis, which checks whether various organizational practices are complementary or substitutable when we consider the objective function (i.e., innovation activity and innovation performance) directly. If practices are complementary, then the objective function is supermodular.

\section{Indirect approach: correlation or adoption analysis}

Complementarities seemingly should create an impact in favour of a positive correlation between two activities. If alternative activities are complementary, rationally 
behaving firms should exploit this opportunity by investing in the activities, at the same time and in the same direction. However, Athey and Stern (1998) note that two activities could be correlated without being complementary; the potential correlation also could be hidden by the influence of a common set of exogenous factors. Therefore, conditional correlations can be calculated according to the residuals of reduced-form regressions of the activities on a set of common observable variables. The presence of positive (negative) conditional correlation coefficients implies potential complementarity (substitutability) between two activities.

This relatively simple approach is the most popular means for testing complementarity (e.g., Arora and Gambardella 1990; Ichniowski, Shaw, and Prennushi 1997; Galia and Legros 2004). It offers evidence of complementarity if activities are adopted simultaneously, without requiring any performance measure. However, it cannot establish conclusively that a complementary relationship exists between two activities. Complementarity may imply, in some conditions, positive correlation, but the reverse is not always true (Catozzella and Vivarelli 2007).

We evaluated complementary relations among different organizational practices by exploring the factors that determine the introduction of these different practices, conditional on a set of observable, firm-related characteristics. We thus derive a multivariate probit model that includes three equations to estimate business practices, workplace organization, and external relations. With this method, we could investigate the correlation across organizational practices, conditional on a set of explanatory variables.

\section{Direct approach: performance analysis}

This approach is based on the objective function of the firm. The simultaneous implementation of different activities should prove more valuable than implementing each activity separately. Therefore, the test of complementarity regresses a measure of firm performance on a set of interaction terms between considered activities, which serve as the complementarity parameters. By comparing the impacts of alternative combinations of activities, it becomes possible to identify complementarity effects between activities. Evidence of complementarity (substitutability) exists if significant and positive (negative) coefficients emerge for the interaction terms. Formally, this approach reflects supermodularity theory (Milgrom and Roberts 1995; Topkis 1998), because if activities are complementary, the objective function is supermodular. The definition of supermodularity provided by Milgrom and Roberts (1995) only requires a non-negative (rather than positive) impact of one practice on the marginal returns of another practice. 
In line with empirical research by Ichniowski, Shaw, and Prennushi (1997), Mohnen and Röller (2005), Cassiman and Veugelers (2006), Lokshin, Belderbos, and Carree (2008), and Carree, Lokshin, and Belderbos (2010), we used a direct, performance-based approach to test for complementarity in our study. We first estimated the probability of observing a (product or process) innovation activity, and then estimated the "innovation function" related to product innovation. These two estimations rely on the alternative combinations of organizational practices as explanatory variables.

Regarding firms' innovation activity, we estimated the following function:

$$
P_{i}^{*}=\sum_{k=0}^{7} S_{k} \gamma_{k}+X_{i}^{\prime} \alpha+\varepsilon_{i}
$$

where $P_{i}^{*}$ is the latent variable corresponding to the probability of innovating products or processes, and $X_{i}$ represents the set of explanatory variables, including controls for firm-level heterogeneity. According to the performance approach (Mohnen and Röller 2005), we inserted a set of state dummy variables $S_{k}$ into the model. With our three binary variables, corresponding to the three organizational practices (business practices, workplace organization, and external relations), we obtained eight dummy variables, $s 0 \_0 \_0, s 0 \_0 \_1, \ldots$, $s 1 \_1 \_1$, representing eight possible combinations. For each state $s k \_l \_m$, the three indices $(k$, $l, m=0,1)$ corresponded to the presence or absence of each of the three practices. Thus for example, $s 1 \_0 \_1$ indicates that business practice and external relations are present but workplace organization is not. Because Equation (1) applies to both product and process innovations, we used a biprobit model to estimate it for product and process innovations separately.

For innovation performance (Mohnen and Röller 2005), we specified the following model:

$$
I_{i}=\sum_{k=0}^{7} S_{k} \delta_{k}+W_{i}^{\prime} \beta+v_{i}
$$

where $I_{i}$ is the innovation performance of firm $i$, measured as the share in sales of innovative products (PERFOR), and $W_{i}$ is the set of control variables. This model only pertains to product innovations, because no similar information is available for process innovations. Only 644 firms innovated products, so we used Heckman's two-step selection model to control for any possible selection bias related to product innovation activity. The second step of the Heckman model corresponds to the performance equation in Equation (2), which can be 
estimated by ordinary least squares; the first step corresponds to a probit estimation of the probability of a product innovation (or propensity to innovate), as given in Equation (1).

Next, we performed supermodularity and submodularity tests for the complementarity and substitutability of innovation activity, in terms of organizational practices. The same tests applied for innovative performance. These tests rely on the coefficients and the covariance matrices obtained from the preceding estimations. Using the definition of supermodularity proposed by Milgrom and Roberts (1990, 1995) and Mohnen and Röller (2005), we let $f(k l m)$ denote the function of interest (i.e., innovation activity in Equation (1); innovative performance in Equation (2)), depending on the absence/presence $(k, l, m=0,1)$ of the three organizational practices (business practices, workplace organization, and external relations). Therefore, the complementarity between practices 1 and 2 can be summarised by two inequalities (similar for the other pairs of practices):

$$
f(10 m)+f(01 m) \leq f(00 m)+f(11 m) \text { where } m=0,1 .
$$

These inequalities can be rewritten as $f(10 m)-f(00 m) \leq f(1 \mathrm{l})-f(01 m), m=0,1$, such that the implementation of practice 1 is more effective when practice 2 is also implemented; equivalently $f(01 m)-f(00 m) \leq f(1 \mathrm{l})-f(10 m), m=0,1$, such that the implementation of practice 2 is more effective when practice 1 is present.

In practice, the tests for complementarity and substitutability in innovation activity were based on consistent estimates of coefficients $\gamma_{n}$ (Equation (1)). As in Mohnen and Röller (2005), complementarity between each pair of practices should satisfy the following constraints: ${ }^{6}$

$$
\begin{aligned}
& \text { (practices } 1 \text { and 2) } \gamma_{4+s}+\gamma_{2+s} \leq \gamma_{0+s}+\gamma_{6+s} \text { where } s=0,1, \\
& \text { (practices } 1 \text { and 3) } \gamma_{4+s}+\gamma_{1+s} \leq \gamma_{0+s}+\gamma_{5+s} \text { where } s=0,2 \text {, and } \\
& \text { (practices } 2 \text { and 3) } \gamma_{2+s}+\gamma_{1+s} \leq \gamma_{0+s}+\gamma_{3+s} \text { where } s=0,4 \text {. }
\end{aligned}
$$

The substitutability of each pair of practices should satisfy analogous inequalities, with opposite signs. The prediction that pair 1-2 is strictly supermodular can be stated formally as follows:

$H_{0}: h_{0}<0$ and $h_{1}<0$ (null hypothesis), and $H_{1}: h_{0} \geq 0$ or $h_{1} \geq 0$ (alternative hypothesis),

\footnotetext{
${ }^{6}$ Recall that practices 1-3 are business practices, workplace organization, and external relations, respectively.
} 
where $h_{s}=-\gamma_{0+s}+\gamma_{2+s}+\gamma_{4+s}-\gamma_{6+s}, s=0,1$. The test is based on Kodde and Palm's (1986) Wald test for inequalities. The tests for other pairs are analogous. Similarly, testing the strict submodularity for pair 1-2 entailed the following hypotheses:

HO: $h 0>0$ and $h 1>0$,

H1: $h 0 \leq 0$ or $h 1 \leq 0$.

We performed the same tests of complementarity and substitutability for product innovation performance, using the parallel estimates from Equation (2) and replacing $\gamma_{k}$ with $\delta_{k}{ }^{7}$

\section{Results and discussion}

\section{Indirect approach}

The results of the multivariate probit model for the complete sample of 2,673 observations appear in Appendix B. We computed the conditional pairwise correlations among the residuals of the three practices from this estimation ${ }^{8}$ (see Table 2). The correlation coefficients between business practices and workplace organization and between business practices and external relations are quite low, negative, and highly significant. These results imply the interdependence of decisions to adopt certain organizational practices, which may be influenced by complementarity in the practices of organizational innovation, or else by omitted firm-specific factors that affect all practices (Belderbos, Carree, and Lokshin 2006).

\section{- INSERT TABLE 2 ABOUT HERE -}

\section{Direct approach}

To investigate the initial, indirect evidence of complementarity, we used the direct approach and directly estimated the firm's performance function with a generalised Tobit model. For the dependent variables in Equations (1) and (2) (percentage of sales attributable to innovative products and probability of being a product innovator), we obtain consistent estimates of the parameters of interest with maximum likelihood estimation, which accounts for censoring in innovation performance (Mohnen and Röller 2005). The inverse Mill's ratio we included in the model to correct for left-censoring was not significant though, so the estimated results for sales of innovative products do not appear influenced by selection bias, as we show in Table 3.

\footnotetext{
${ }^{7}$ These tests also can be performed on the selection equation for product innovation using Heckman's selection model with Equation (2). They are consistent with those based on Equation (1), as applied to product innovation. ${ }^{8}$ Recall that these correlations are conditional on a set of observable, firm-related characteristics, such as firm size, sector of activity, and group belonging.
} 


\section{- INSERT TABLE 3 ABOUT HERE -}

To analyse the complementary relationship of the three organizational practices, we also assessed the impact of organizational practices on the probability that the firm was a product and process innovator, using a biprobit model (Table 4).

\section{- INSERT TABLE 4 ABOUT HERE -}

The results in both Tables 3 and 4 show that the probability of being a process innovator and product innovative performance depend on $R \& D$ intensity, in line with previous empirical findings regarding the crucial role of internal $R \& D$ expenditures for innovation (Crépon, Duguet, and Mairesse 1998). However, R\&D intensity had no significant impact on the probability of being a product innovator. Firm size correlated positively with the likelihood of product and process innovations but negatively with product innovative performance. That is, the larger the firm, the greater its propensity to innovate in products but the weaker its innovative performance, in line with previous empirical findings (Mohnen and Röller 2005).

For organizational innovation practices, we found that when they were adopted separately, business practices and external relations exerted impacts on product innovation performance, but their effects were lower than that produced by their joint implementation. Workplace organization also had a significant impact on the propensity to innovate in both products and processes. The simultaneous implementation of workplace organization and business practices was significantly associated with the propensity to innovate in products and processes, compared with the reference case of simultaneous implementation of all three practices (s1_1_l). No effects of such combinations emerged for innovative performance though.

Although these results hint at the effects of different combinations of organizational practices on innovation output, the individual significance levels and signs of the coefficients alone cannot confirm the complementarity of different organizational practices. Instead, testing for complementarity demands linear inequality restrictions and the joint distribution of several restrictions (Mohnen and Röller 2005; Love and Roper 2009). For our study, assessing the complementarity of organizational practices required joint tests of two inequality constraints for each pairwise comparison. We provide the results of the supermodularity and submodularity tests in Tables 5 and 6 .

\section{- INSERT TABLES 5 AND 6 ABOUT HERE -}

Similar to Mohnen and Röller (2005), we rely on the values provided by Kodde and Palm (1986) for the lower and the upper bounds of the tests at the $10 \%$ significance level. The numbers of degrees of freedom are computed as 1 plus the number of equality restrictions $(q$ 
+1 ) for the lower bound and as the total number of equality and inequality restrictions $(p)$ for the upper bound. For the models in Equations (1) and (2), referring to product and process innovations and product innovation performance, respectively, the lower and upper bounds at the $10 \%$ level were 1.642 ( $\mathrm{df}=1$, no equality restriction) and 3.804 ( $\mathrm{df}=2$, with two inequality restrictions). The null hypothesis $H_{0}$ must be rejected if the test statistic is higher than the upper bound but accepted if the test statistic is lower than the lower bound (it would be inconclusive for values between the two bounds).

The results in Tables 5 and 6 reveal that the pattern of complementarity across organizational practices depends on the type of innovation (product or process). For the propensity to innovate (Table 6), we find significant evidence of complementarity between business practices and external relations (pair 1-3) with an effect on product innovation, in partial support of $\mathrm{P} 1$. That is, firms that combine these two practices tend to benefit more from flexibility, adaptability, and knowledge increases, which may lead to a higher capacity to introduce innovation. Contrary to $\mathrm{P} 3$, the pair 1-2 is substitutable; the joint implementation of business practices and workplace organization actually decreases the propensity to innovate in products. Instead, implementing one of these two practices should be sufficient to motivate a firm to innovate, whereas the benefits of low levels of hierarchy, greater delegation, broad skills, teamwork, and job rotation get mitigated when firms implement them together with workplace organization (lean production, supply chain management, business reengineering, quality management). This finding may reflect the high costs that firms would have to incur to implement such practices simultaneously, such that doing so would impede rather than stimulate firm innovation capacities. Finally, the results for the pair 2-3 (P2) are not clear, because the test indicates both supermodularity and submodularity.

For process innovation, we find that business practices and external relations (pair 13) are complementary, in further support of $\mathrm{P} 1$, whereas the effects of combining business practices and workplace organization (pair 1-2) or workplace organization and external relations (pair 2-3) are not clear.

Patterns of complementarity also may differ according to whether the firm is in the first step of the innovation process (i.e., being a product innovator or not, Table 6) or a subsequent step (i.e., product innovative performance, Table 5). The complementary relationship between business practices and external relations (pair 1-3) emerged for both propensities for product and process innovation and product innovative performance, in strong support of P1. The pattern of complementarity was the same for the relationship between workplace organization and external relations (pair 2-3): We observe a 
complementarity effect on technological innovation performance, in partial support of P2. Therefore, we predict that firms achieve higher performance from new products when they can combine these two organizational practices. Similarly, the relationship between business practices and workplace organization (pair 1-2, P3) was complementary in its effect on innovation performance but substitutable when considering propensity for product innovation. This result is in line with competence theory: In modern business environments, strategic costs and quality management are critical factors for firms' commercial success, and they need to be implemented jointly within a high performance work organization that simultaneously facilitates knowledge integration, information exchange, and mutual learning (Grabher 2001).

\section{Conclusions, limitations, and further research}

This study examines innovation within the context of complementary organizational strategies and innovation performance, in an attempt to understand whether different organizational innovation practices are complements or substitutes for technological innovation performance. We used supermodularity theory (Milgrom and Roberts 1990, 1995), which makes it possible to create supermodular functions to demonstrate the effect of complementarity across organizational strategies for technological innovation. In our two-step analysis, we first analysed the conditional correlation among organizational practices, then tested the impact of simultaneous combinations of practices on firms' innovativeness directly, measured as both the probability of being an innovator (product and process) and the share of sales stemming from innovative products. In this sense, we investigated two "phases" of the innovation process: the decision to innovate or not and product/process innovation performance, conditional on the firm undertaking any innovation at all. Our empirical study relied on firm-level data drawn from the French CIS (2008). To the best of our knowledge, this study is the first to assess firms' organizational innovation management from an integrative and holistic perspective by analysing the pattern of complementarity of different organizational practices, according to their impact on firms' innovation, while also taking into account different measures of innovation performance (being innovative or not on one hand, product and process innovations on the other hand).

Regarding the relationships of organizational practices, the results from the two approaches we used differed. The correlation approach suggested that all pairwise combinations of organizational practices were correlated, even when we controlled for the exogenous variables. The performance approach relies on significant pairwise combinations, 
so it is important to note that other (unobserved) underlying factors may cause the correlation, instead of complementarity. In line with previous empirical evidence of the complementarities of individual organizational practices in firms - in particular, organizational policies, practices, structures, and processes (Ennen and Richter 2010) — this study provides evidence of the presence of complementarities or substitution effects in these relationships.

Our robust empirical approach offers partial support for our three propositions, though it also highlights the controversial outcomes of these effects, depending on the phase of innovation considered. Yet this study offers important evidence about the relationships of organizational practices. First, we denote the crucial role of organizational innovation, in that our empirical results affirm a positive impact of complementary organizational practices on firms' innovation and thereby support previous theoretical studies (Teece 1986; Stieglitz and Heine 2007).

Second, the patterns of complementarity across organizational practices differ according to the type of innovation (product or process), though with some similarities. For example, the joint implementation of business practices and workplace organization is substitutable in its effect on the probability to innovate in products, but the effect is not clear for the probability of being a process innovator. The joint implementation of business practices and external relations has a complementary effect for both product and process innovations. Thus, the two types of innovation appear subject to different organizational management tools.

Third, the patterns of complementarity differ according to the measure of technological innovation performance. We found complementary relationships among all organizational practices for product innovation performance, but the results for the propensity to innovate in products and processes indicate several substitutable relationships or else inconclusive evidence. Business practices, when implemented simultaneously with workplace organization, paid off more than their isolated adoption, in terms of product innovation performance. Yet we uncovered a substitutable relationship between business practices and workplace organization for the propensity to innovate in products. These differences might emerge because logically, business practices cannot help firms become innovators; other determinants are more important. However, such practices are necessary to ensure the success of innovative products; for example, supply chain management ensures efficient relationships with suppliers and customers, and quality management offers more customer value by enhancing product quality. 
These results strongly highlight the complexity of managing organizational practices as a means to increase firms' innovation, much less combining organizational innovation practices to reinforce technological innovation performance. Some practices clearly should be adopted simultaneously to achieve an optimal effect, but others are productive on their ownand still others are counterproductive for innovation. Managers therefore must attend carefully to the various effects of organizational innovation practices for technological innovation. Studying such relationships among individual elements or factors, especially organizational innovation practices, can offer valuable insights (Ennen and Richter 2010). This study seeks to help firms, with their inherently limited resources, choose appropriate organizational innovation practices for their subsequent technological innovation.

Yet our study also suffers certain limitations that suggest the empirical evidence we present needs to be received with some caution. First, the theoretical framework of complementarities in organizational innovation remains under construction. Prior research tends to focus on technological innovation on one hand and on work or human resource practices, in terms of complementarities, on the other hand. Similar to Laursen and Foss (2003, 257), we have not offered a fine-tuned theory about why such complementarities between various organizational practices exist, which "is very clearly a theoretical deficit in this area." Further work should be devoted to theorizing the links between complementary organizational practices and innovation performance more comprehensively, especially because most studies of such complementarities remain empirical in nature.

Second, our study reflects the "crude definitions and indicators of organizational innovation adopted by CIS" (Evangelista and Vezzano 2010, 1262). Our focus on a single country is an obvious limitation, though cross-country comparisons are difficult, because various national CIS rely on different definitions of organizational innovation practices. Further research might address this difficulty by comparing countries that use similar designs, such as France and Luxembourg. Moreover, as Armbruster et al. (2008) suggest, it would be interesting to compare these results with other large-scale surveys (e.g., NUTEK, DRUID, EPOC, INNFORM, COI) that use different measures of both organizational innovations and technological innovation, to determine if the results generalise to other types of organizational practices. Such an effort might help resolve the issue of partial overlap across some suborganizational dimensions contained in the CIS categories. ${ }^{9}$

\footnotetext{
${ }^{9}$ We thank an anonymous reviewer for this suggestion.
} 
Third, our results are static and only tentative; the causal direction cannot be confirmed without longitudinal, dynamic studies. Widespread recognition cites the problems that arise when researchers attempt to address econometric endogeneity issues and make statements about causality using cross-sectional data. It simply is not possible to determine with these data whether the same firms are innovative every year or what keeps firms innovative over time. Further research should use dynamic panel data to analyse the complementarities of technological and organizational - or more generally, non-technological (including marketing) - innovations. In our case though, the definition and categories of organizational innovation have changed with each CIS survey.

Fourth and finally, this study focused on organizational strategies and their complementary effects on technological innovation. Our mixed results thus must be partly due to the limited number of organizational practices we consider. Further studies should investigate more non-technological innovation practices, such as marketing, management, or strategic innovations (Battisti and Stoneman 2010), as well as resources, strategies, and external factors (e.g., demand conditions, institutional environment; Ennen and Richter 2010), to better reflect the original idea of the supermodular modern manufacturing firm (Milgrom and Roberts 1990). A study with multiple elements could yield more complementarity effects, which are largely system-specific phenomena (Ennen and Richter 2010). Thus, our study represents a small step along the path to understanding the variety of innovation patterns and complementarities, especially for organizational and technological innovations. Much work remains to comprehend complementary effects across different types of innovation.

\section{References}

Alegre, J., and R. Chiva. 2008. “Assessing the Impact of Organizational Learning Capability on Product Innovation Performance: An Empirical Test.” Technovation 28(6): 315-326.

Alegre, J., Sengupta, K., and R. Lapiedra. 2013. "Knowledge Management and Innovation Performance in a High-tech SMEs Industry.” International Small Business Journal 31(4): 454-470.

Armbruster, H., Bikfalvib, A., Kinkela, S., and G. Lay. 2008. "Organizational Innovation: The Challenge of Measuring Non-technical Innovation in Large-scale Surveys.” Technovation 28(10): 644-657.

Arora, A., and A. Gambardella. 1990. "Complementarity and External Linkages: The Strategies of the Large Firms in Biotechnology." Journal of Industrial Economics 38(4): 362-379. 
Athey, S., and S. Stern. 1998. "An empirical framework for testing theories about complementarity in organizational design.” NBER Working Paper 6600, Massachusetts. http://kuznets.fas.harvard.edu/ athey/testcomp0498.pdf

Baldridge, J., and R.A. Burnham. 1975. "Organizational innovation: Individual, organizational, and environmental impacts." Administrative Science Quarterly 20(2): 165-176.

Battisti, G., and A. Iona. 2009. "The intra-firm diffusion of complementary innovations: Evidence from the adoption of management practices by British establishments." Research Policy 38(8): 1326-1339.

Battisti, G., and P. Stoneman. 2010. "How innovative are UK firms? Evidence from the Fourth UK Community Innovation Survey on synergies between technological and organizational innovations.” British Journal of Management 21(1): 187-206.

Belderbos, R., Carree, M., and B. Lokshin. 2006. "Complementarity in R\&D cooperation strategies." Review of Industrial Organization 28(4): 401-426.

Benner, M. J., and M. Tushman. 2002. "Process Management and Technological Innovation: A Longitudinal Study of the Photography and Paint Industries." Administrative Science Quarterly 47(4): 676-706.

Beugelsdijk, S. 2008. "Strategic Human Resource Practices and Product Innovation." Organization Studies 29(6): 821-847.

Bharadwaj, S., and A. Menon. 2000. "Making Innovation Happen in Organizations: Individual Creativity Mechanisms, Organizational Creativity Mechanisms or Both?" Journal of Product Innovation Management 17(6): 424-434.

Birkinshaw, J., Hol, M. J., and G. Hamel. 2008. "Management Innovation.” Academy of Management Review 33(4): 825-845.

Bresnahan, T.F., Brynjolfsson, E., and L.M Hitt. 2002. "Information Technology, Workplace Organization, and the Demand for Skilled Labor: Firm-level Evidence.” The Quarterly Journal of Economics 117(1): 339-376.

Cappelli, P., and D. Newmark. 2001. "Do High-performance Work Practices Improve Establishment-level Outcomes?” Industrial \& Labor Relations Review 54(4): 737-775.

Carree, M., Lokshin, B., and R. Belderbos. 2011. "A Note on Testing for Complementarity and Substitutability in the Case of Multiple Practices." Journal of Productivity Analysis 35(3): 263-269. 
Cassiman, B., and R. Veugelers. 2006. "In Search of Complementarity in Innovation Strategy: Internal R\&D, Cooperation in R\&D and External Technology Acquisition." Management Science 52(1): 68-82.

Catozzella, A., and M. Vivarelli. 2007. "Beyond the Knowledge Production Function: The

Role of R\&D in a Multi-faceted Innovation Process.” Jena Economic Research Papers in Economics, 01/2007; DOI:10.2139/ssrn.1029664.

Chen, C., and J. Huang. 2009. "Strategic Human Resource Practices and Innovation Performance - The Mediating Role of Knowledge Management Capacity." Journal of Business Research 62(1): 104-114.

Cohen, W.M., and D.A. Levinthal. 1990. "Absorptive Capacity: A New Perspective on Learning and Innovation.” Administrative Science Quarterly 35(1): 128-152.

Cozzarin, B.P., and J.C. Percival. 2006. "Complementarities Between Organisational Strategies and Innovation." Economics of Innovation and New Technology 15(3): 195217.

Crépon, B., Duguet, M., and J. Mairesse. 1998. "Research and Development, Innovation and Productivity: An Econometric Analysis at the Firm Level.” Economics of Innovation and New Technology 7(2): 115-158.

Crossan, M.M., and M. Apaydin. 2010. “A Multi-dimensional Framework of Organizational Innovation: a Systematic Review of the Literature." Journal of Management Studies 47(6): 1154-1191.

Daft R.L. 1978. “A Dual-core Model of Organizational Innovation.” Academy of Management Journal 21(2): 193-210.

Damanpour, F. 2010. “An Integration of Research Findings of Effects of Firm Size and Market Competition on Product and Process Innovations." British Journal of Management 21(4): 996-1010.

Damanpour, F., and W.M. Evan. 1984. "Organizational Innovation and Performance: The Problem of “Organizational Lag”." Administrative Science Quarterly 29(3): 392-409. Damanpour, F., and D. Aravind. 2006. "Product and Process Innovations: A Review of Organizational and Environmental Determinants.” In Innovation, science, and institutional change. Edited by Hage, J. and M. Meeus. Oxford: Oxford University Press.

De Cock, C., and I. Hipkin. 1997. "TQM and BPR: Beyond the Beyond Myth." Journal of Management Studies 34(5): 659-675. 
Domanovic, V., and V. Stojanovic-Aleksic. 2010. "The Complementariness of the Business Process Reengineering and Activity-based Management." Scientific Bulletin - Economic Sciences 9(15): 123-130.

Ennen, E., and A. Richter. 2010. "The Whole is More Than the Sum of its Parts—or Is it? A Review of the Empirical Literature on Complementarities in Organizations." Journal of Management 36(1): 207-233.

Ettlie, J.E., and E.M. Reza. 1992. "Organizational Integration and Process Innovation." Academy of Management Journal 35(4): 795-827.

European Commission, 1997. “Green paper”. Accessed 17 may 2012. http://europa.eu.int/comm/employment_social/.

Evangelista, R., and A. Vezzani. 2010. "The Economic Impact of Technological and Organizational Innovations. A firm-level analysis.” Research Policy 39(10): 1253-1263.

Foss, N. J., Laursen, K., and T. Pedersen. 2010. "Linking Customer Interaction and Innovation: The Mediating Role of New Organisational Practices." Organization Science 22(4): 980-999.

Galia, F., and D. Legros. 2004. "Complementarities Between Obstacles to Innovation: Evidence from France." Research Policy 33(8): 1185-1199.

Galia, F., 2007. "Incentives, Competencies and Knowledge: Evidence from France and Theoretical Integration.” Organizações em context 3(5): 129-163.

Gebert, D., Boerner., S., and E. Kearney. 2010. "Fostering Team Innovation: Why is it Important to Combine Opposing Action Strategies?” Organization Science 21(3): 593608.

Germain, R. 1996. "The Role of Context and Structure in Radical and Incremental Logistics Innovation Adoption.” Journal of Business Research 35(2): 117-127.

Grabher, G. 2001. "Locating Economic Action: Projects, Networks, Localities, Institutions." Environment and Planning A 33(8): 1329 - 1331.

Grant, R.M. 1996. “Toward a Knowledge-based Theory of the Firm.” Strategic Management Journal 17(special issue): 109-122.

Gumusluoğlu, L., and A. Ilsev. 2009. "Transformational Leadership and Organizational Innovation: The Roles of Internal and External Support for Innovation." Journal of Product Innovation Management 26(3): 264-277.

Günday, G., Ulusoy, G., K1lıç, K., and L. Alpkan. 2011. "Effects of Innovation Types on Firm Performance.” International Journal of Production Economics 133(2): 662-676. 
Hempell, T., and T. Zwick. (2008). "New Technology, Work Organisation, and Innovation." Economics of Innovation \& New Technology 17(4): 331-354.

Ichniowski, C., Shaw, K., and G. Prennushi. 1997. "The Effects of Human Resource Management Practices on Productivity: A Study of Steel Finishing Lines." American Economic Review 87(3): 291-313.

Kimberly, J.R., and M. Evanisko. 1981. "Organizational Innovation: The Influence of Individual, Organizational, and Contextual Factors on Hospital Adoption of Technological and Administrative Innovations." Academy of Management Journal 24(4): 679-713.

Khanagha, S., Volberda, H., Sidhu, J., and I. Oshri. 2013. "Management Innovation and Adoption of Emerging Technologies: The Case of Cloud Computing." European Management Review 10(1): 51-67.

Kodde, D.A., and F.C. Palm. 1986. "Wald Criteria for Jointly Testing Equality and Inequality Restrictions." Econometrica 54(5): 1243-1248.

Kogut, B., and U. Zander. 1993. "Knowledge of the Firm and the Evolutionary Theory of the Multinational Corporation.” Journal of International Business Studies 24(4): 625-645.

Kuhn, D. 2010. “Complementarities Between Workplace Organisation and Human Resource Management: Evidence from Swiss Firm-level Panel Data.” Discussion Paper 2010/03. Wirtschaftswissenschaftliches Zentrum (WWZ), Basel University.

Laursen, K., and V. Mahnke. 2001. "Knowledge Strategies, Firm Types, and Complementarity in Human-resource Practices." Journal of Management and Governance 5(1): 1-27.

Laursen, K., and N.J. Foss. 2003. "New Human Resource Management Practices, Complementarities and the Impact on Innovation Performance." Cambridge Journal of Economics 27(2): 243-263.

Learned, E.P., Christensen, C.R., Andrews, K.R., and W.D. Guth. 1961. Business Policy: Text and Cases. Homewood, IL: Irwin.

Lokshin, B., Belderbos, R., and M. Carree. 2008. "The Productivity Effects of Internal and External R\&D. Evidence from a Dynamic Panel Data Model." Oxford Bulletin of Economics and Statistics 70(3): 399-413.

López-Cabrales, A., Pérez-Luño A., and R. Valle-Cabrera. 2009. "Knowledge as a Mediator Between HRM Practices and Innovative Activity." Human Resource Management 48(4): 485-503. 
Love, J.H., and R. Roper. 2009. “Organizing Innovation: Complementarities Between Crossfunctional Teams." Technovation 29(3): 192-203.

Mantovani, A. 2006. "Complementarity Between Product and Process Innovation in a Monopoly Setting." Economics of Innovation and New Technology 15(3): 219-234.

Michie, J., and M. Sheehan. 2003. "Labour Market Deregulation, 'Flexibility' and Innovation." Cambridge Journal of Economics 27(1): 123-143.

Milgrom, P., and J. Roberts. 1990. "The Economics of Modern Manufacturing: Technology, Strategy and Organization." American Economic Review 80(3): 511-28.

Milgrom, P., and J. Roberts. 1995. "Complementarities and Fit: Strategy, Structure and Organizational Change in Manufacturing." Journal of Accounting and Economics 19(23): 179-208.

Miravete, E.J., and J.C. Pernias. 2006. "Innovation Complementarity and Scale of Production.” Journal of Industrial Economics 54(1): 1-29.

Mohnen, P., L Röller. 2005. "Complementarities in Innovation Policy.” European Economic Review 49(6): 1431-1450.

Mol, M.J, and J.M. Birkinshaw. 2009. "Management Innovation: A Problemistic Search Perspective on why Firms Introduce New Management Practices." Journal of Business Research 62(12): 1269-1280.

Mol, M. J., and J.M. Birkinshaw. 2012. "Relating Management Innovation to Product and Process Innovation: Private Rents Versus Public Gains”. In Handbook of Organizational and Managerial Innovation. Edited by Tyrone S. Pitsis, 13-35. Edward Elgar Publishing.

Nelson, R.R., and S.G. Winter. 1982. An Evolutionary Theory of Economic Change. Cambridge, MA: Bellknap.

OECD. 2005. Oslo Manual. 3d ed., OECD/Eurostat: OECD Publishing.

Palacios, D., Gil, I., and F. Garrigos. 2009. "The Impact of Knowledge Management on Innovation and Entrepreneurship in the Biotechnology and Telecommunications Industries.” Small Business Economics 32(3): 291-301.

Penrose, E.T. 1959. The Theory of the Growth of the Firm. New York: John Wiley.

Perdomo-Ortiz, J., Gonzalez-Benito, J., and J. Galende. 2009. "The Intervening Effect of Business Innovation Capability on the Relationship Between Total Quality Management and Technological Innovation.” International Journal of Production Research 47(18): 5087-5107.

Prajogo, D.I., and A.S. Sohal. 2001. "TQM and Innovation: A Literature Review and Research Framework." Technovation 21(9): 539-558. 
Prajogo, D.I., and A.S. Sohal. 2004. "The Multidimensionality of TQM Practices in Determining Quality and Innovation Performance-an Empirical Examination.” Technovation 24(6): 443-515.

Romijn, H., and M. Albaladejo. 2002. "Determinants of Innovation Capability in Small Electronics and Software firms in Southeast England." Research Policy 31(7): 10531067.

Sakakibara, M. 1997. "Heterogeneity of Firm Capabilities and Co-operative Research and Development: An Empirical Examination of Motives.” Strategic Management Journal 18(6): 143-16.

Schmidt, T., and C. Rammer. 2007. "Non-technological and Technological Innovation: Strange Bedfellows?" Working Paper 07-052, ZEW. Accessed June 5, 2012 , ftp://ftp.zew.de/pub/zew- docs/dp/dp07052.pdf.

Schmiedeberg, C. 2008. "Complementarities of Innovation Activities: an Empirical Analysis of the German Manufacturing Sector.” Research Policy 37(9): 1492-1503.

Staropoli, C. 1998. "Cooperation in R\&D in the Pharmaceutical Industry: The Network as an Organizational Innovation Governing Technological Innovation.” Technovation 18(1): 13-23.

Stieglitz, N., and K Heine. 2007. "Innovations and the Role of Complementarities in a Strategic Theory of the Firm.” Strategic Management Journal 28(1): 1-15.

Tatikonda, M.V., and M.M. Montoya-Weiss. 2001. "Integrating Operations and Marketing Perspectives of Product Innovation: The Influence of Organizational Process Factors and Capabilities on Development Performance.” Management Science 47(1): 151-172.

Teece, D.J. 1986. "Profiting from Technological Innovation." Research Policy 15(6): 285305.

Teece, D.J. 1988. "Technical Change and the Nature of the Firm." In Technical Change and Economic Theory, edited by Dosi, G., Freeman, C., Nelson, R. and L. Soete, 256-281. Pinter: New York.

Teece, D.J. 2007. "Explicating Dynamic Capabilities: The Nature and Microfoundations of (Sustainable) Enterprise Performance.” Strategic Management Journal 28(13): 1319-50. Topkis, D.M. 1998. Supermodularity and Complementarity. Princeton University Press, New Jersey.

Vasudeva, G., and J. Anand. 2011. "Unpacking Absorptive Capacity: A Study of Knowledge Utilization from Alliance Portfolios.” Academy of Management Journal 54(3): 611-623. 
Zhang, H., Shu, C., Jiang, X., and A. Malter. 2010. "Managing Knowledge for Innovation: The Role of Cooperation, Competition, and Alliance Nationality." Journal of International Marketing 18(4): 74-94.

Zhou, K.B., and C.B. Li. 2012. "How Knowledge Affects Radical Innovation: Knowledge Base, Market Knowledge Acquisition, and Internal Knowledge Sharing." Strategic Management Journal 33(9): 1090-1102.

Zoghi, C., Mohr, R.D., and P.B. Meyer. 2010. "Workplace Organisation and Innovation." Canadian Journal of Economics 43(2): 622-639. 
Table 1. Distribution of combinations of organizational practices

\begin{tabular}{lll}
\hline \hline States & Frequency & Percentage \\
\hline sO_0_0 & 1037 & 38.8 \\
sO_0_1 & 55 & 2.06 \\
sO_1_0 & 156 & 5.84 \\
sO_1_l & 59 & 2.21 \\
s1_0_0 & 264 & 9.88 \\
s1_0_1 & 56 & 2.10 \\
s1_1_0 & 543 & 20.31 \\
s1_1_l & 503 & 18.83 \\
\hline Total & 2673 & 100 \\
\hline \hline
\end{tabular}

Notes. The variables $s k \_l \_m$ (where $k, l, m=0,1$ ) correspond to the eight possible combinations of three binary variables, representing three organizational practices $\left(k=\right.$ business practices, $l=$ workplace organization, $m=$ external relations). Thus $s 1 \_0 \_1$ corresponds to the case in which only business practices and external relations are present.

Table 2. Conditional correlations of organizational practices

\begin{tabular}{llll}
\hline \hline & Business practices & Workplace organization & External relations \\
\hline Business practices & 1.000 & & \\
Workplace organization & $-0.214^{* * *}$ & 1.000 & \multirow{2}{*}{1.000} \\
External relations & $-0.215^{* *}$ & 0.064 & \\
\hline \hline
\end{tabular}


Table 3: Estimation results for product innovative performance

\begin{tabular}{lll}
\hline \hline Variables & Coefficient & (Standard Error) \\
\hline SO_0_0 & $-0.044^{* * *}$ & $(0.014)$ \\
sO_0_1 & $-0.050^{* * *}$ & $(0.024)$ \\
SO_1_0 & -0.010 & $(0.022)$ \\
sO_1_1 & -0.032 & $(0.026)$ \\
s1_0_0 & $-0.045^{* * *}$ & $(0.017)$ \\
s1_0_1 & $-0.064^{* * *}$ & $(0.020)$ \\
s1_1_0 & -0.014 & $(0.013)$ \\
Firm size & $-0.013^{* * *}$ & $(0.004)$ \\
Group & -0.009 & $(0.014)$ \\
R\&D intensity & $0.116^{*}$ & $(0.060)$ \\
Demand-pull & -0.012 & $(0.020)$ \\
Cost-push & -0.005 & $(0.008)$ \\
High-tech & 0.017 & $(0.016)$ \\
Med high-tech & 0.014 & $(0.013)$ \\
Medlow-tech & $0.021^{*}$ & $(0.013)$ \\
Intercept & $0.228^{* * *}$ & $(0.040)$ \\
Inverted Mill's ratio & -0.007 & $(0.035)$ \\
\hline \hline
\end{tabular}

Notes. The dependent variable is innovative performance, measured as the share of sales of innovative products. Estimation results came from a Heckman two-step selection model (selection equation for product innovation, followed by performance equation for product innovation). The variables $s k \_l \_m$ (where $\left.k, l, m=0,1\right)$ correspond to the eight possible combinations of three binary variables, representing three organizational practices $(k=$ business practices, $l=$ workplace organization, $m=$ external relations). Number of observations $=2673$. Number of censored observations $=644$.

$*$, **, and $* * *$ denote significance at the $10 \%, 5 \%$, and $1 \%$ levels, respectively, based on bootstrap standard errors with 100 replications. 
Table 4: Estimation results for product and process innovations

\begin{tabular}{|c|c|c|c|c|}
\hline \multirow{3}{*}{$\frac{\text { Variable }}{\text { sO_O_O }}$} & \multirow{2}{*}{\multicolumn{2}{|c|}{$\begin{array}{l}\text { Product innovation } \\
\text { Coefficient (SE) }\end{array}$}} & \multirow{2}{*}{\multicolumn{2}{|c|}{$\begin{array}{l}\text { Process innovation } \\
\text { Coefficient (SE) }\end{array}$}} \\
\hline & & & & \\
\hline & $-0.224 * * *$ & $(0.080)$ & $-1.054 * * *$ & $(0.100)$ \\
\hline sO_O_l & $-0.486 * *$ & $(0.202)$ & $-0.623 * * *$ & $(0.210)$ \\
\hline sO_1_O & $-0.274 * *$ & $(0.127)$ & $-0.746^{* * *}$ & $(0.125)$ \\
\hline sO_1_l & -0.191 & $(0.217)$ & -0.323 & $(0.212)$ \\
\hline s1_O_O & -0.163 & $(0.109)$ & $-0.504 * * *$ & $(0.132)$ \\
\hline s1_O_l & 0.377 & $(0.536)$ & 0.531 & (1.433) \\
\hline s1_1_0 & $-0.167 *$ & $(0.086)$ & $-0.276^{* *}$ & $(0.117)$ \\
\hline Firm size & $0.141 * * *$ & $(0.027)$ & $0.053 * *$ & $(0.023)$ \\
\hline Group & -0.077 & $(0.074)$ & 0.092 & $(0.071)$ \\
\hline $\mathrm{R} \& \mathrm{D}$ intensity & -0.156 & $(0.353)$ & $1.934 * * *$ & $(0.670)$ \\
\hline Internal sources & $0.476 * * *$ & $(0.057)$ & -0.083 & $(0.064)$ \\
\hline Market sources & $0.304 * * *$ & $(0.058)$ & 0.054 & $(0.060)$ \\
\hline Institutional sources & -0.071 & $(0.150)$ & -0.024 & $(0.124)$ \\
\hline Other sources & $0.277 * * *$ & $(0.083)$ & -0.036 & $(0.080)$ \\
\hline High-tech & $0.214 *$ & $(0.110)$ & $-0.268 * *$ & $(0.115)$ \\
\hline Med high-tech & $0.487 * * *$ & $(0.075)$ & $-0.240 * * *$ & $(0.070)$ \\
\hline Med low-tech & 0.029 & $(0.062)$ & -0.027 & $(0.069)$ \\
\hline Intercept & $1.084 * * *$ & $(0.150)$ & $1.022 * * *$ & $(0.129)$ \\
\hline
\end{tabular}

\begin{tabular}{|c|c|}
\hline $\operatorname{atanh} \rho$ & $-0.371 * * *$ \\
\hline $\operatorname{LR} \chi^{2}(1)$ & $84.533 * * *$ \\
\hline Log likelihood & -2664.834 \\
\hline
\end{tabular}


Table 5: Supermodularity and submodularity tests for product innovation performance

\begin{tabular}{llll}
\hline \hline Wald test & Pair 1-2 & Pair 1-3 & Pair 2-3 \\
\hline Supermodularity & $0.005 \mathrm{~A}$ & $0.180 \mathrm{~A}$ & $0.178 \mathrm{~A}$ \\
Submodularity & $15.739 \mathrm{R}$ & $23.343 \mathrm{R}$ & $25.242 \mathrm{R}$
\end{tabular}

Notes. Tests are based on consistent estimates for the equation of product innovative performance (Heckman's model). The lower and the upper bounds of the test at the $10 \%$ level (see Kodde and Palm 1986) are $1.642(\mathrm{df}=1)$ and $3.808(\mathrm{df}=2)$.

A The null hypothesis $H_{0}$ is accepted (test statistic is lower than the lower bound).

${ }^{\mathrm{R}} H_{0}$ is rejected (test statistic is higher than the upper bound).

$\mathrm{N}_{\text {No conclusion (otherwise). }}$

Table 6: Supermodularity and submodularity tests for product and process innovation

\begin{tabular}{lllll}
\hline \hline & Wald test & Pair 1-2 & Pair 1-3 & Pair 2-3 \\
\hline Product & Supermodularity & $2.728 \mathrm{~N}$ & $0.691 \mathrm{~A}$ & $1.571 \mathrm{~A}$ \\
& Submodularity & $0.116 \mathrm{~A}$ & $2.070 \mathrm{~N}$ & $1.330 \mathrm{~A}$ \\
\hline Process & Supermodularity & $0.302 \mathrm{~A}$ & $0.000 \mathrm{~A}$ & $0.000 \mathrm{~A}$ \\
& Submodularity & $0.017 \mathrm{~A}$ & $9.021 \mathrm{R}$ & $0.034 \mathrm{~A}$ \\
\hline
\end{tabular}

Notes. Tests are based on consistent estimates of product and process innovations (biprobit regression). The lower and the upper bounds of the test at the $10 \%$ level (see Kodde and Palm 1986) are $1.642(\mathrm{df}=1)$ and $3.808(\mathrm{df}=2)$.

A The null hypothesis $H_{0}$ is accepted (test statistic is lower than the lower bound).

$\mathrm{R}_{H_{0}}$ is rejected (test statistic is higher than the upper bound).

$\mathrm{N}_{\text {No conclusion (otherwise). }}$ 
Appendix A. Variable definitions

\begin{tabular}{|c|c|c|c|}
\hline Variables & Description & Mean & SD \\
\hline $\begin{array}{l}\text { Innovation } \\
\text { performance } \\
\text { Propensity } \\
\text { to innovate } \\
\text { in product } \\
\text { Propensity } \\
\text { to innovate } \\
\text { in process } \\
\text { Organization }\end{array}$ & $\begin{array}{l}\text { Percentage of total turnover in } 2006 \text { from goods and service innovations } \\
\text { introduced during } 2006 \text { to } 2008 \text { that are new to the firm } \\
\text { Equal } 1 \text { if the firm introduced new or significantly improved goods or } \\
\text { services during the three years } 2006 \text { to } 2008,0 \text { otherwise } \\
\text { Equal } 1 \text { if the firm introduced new or significantly improved production } \\
\text { process, distribution methods, or support activity for goods or services } \\
\text { during the three years } 2006 \text { to } 2008,0 \text { otherwise } \\
\text { al innovation practices }\end{array}$ & 0.741 & 0.438 \\
\hline $\begin{array}{l}\text { External } \\
\text { relations } \\
\text { Sources of } \\
\text { information }\end{array}$ & $\begin{array}{l}\text { Equal } 1 \text { if the firm introduced new business practices for organizing } \\
\text { work or procedures (i.e. supply chain, business re-engineering, lean } \\
\text { production, quality management, knowledge management), } 0 \text { otherwise } \\
\text { Equal } 1 \text { if the firm introduced new methods of workplace organization } \\
\text { for distributing responsibilities and decision making (team work, } \\
\text { decentralization, integration or de-integration of departments), } 0 \\
\text { otherwise } \\
\text { Equal } 1 \text { if the firm introduced new methods of organizing external } \\
\text { relations with other firms or public institutions (partnerships, } \\
\text { outsourcing, sub-contracting), } 0 \text { otherwise }\end{array}$ & 0.252 & 0.499 \\
\hline $\begin{array}{l}\text { Internal } \\
\text { sources } \\
\text { Institutional } \\
\text { sources }\end{array}$ & $\begin{array}{l}\text { Binary variable, equal to } 1 \text { if sources of information stemming from } \\
\text { other firms belonging to the same group are crucial for the firm's } \\
\text { innovation activities, } 0 \text { otherwise. } \\
\text { Binary variable, equal to } 1 \text { if sources of information stemming from } \\
\text { universities, other higher education institutions, government, consultants, } \\
\text { commercial labs, private R\&D institutes, or public research institutes are } \\
\text { crucial for the firm's innovation activities, } 0 \text { otherwise. }\end{array}$ & 0.047 & 0.212 \\
\hline $\begin{array}{l}\text { Market } \\
\text { sources } \\
\text { Other } \\
\text { sources } \\
\text { Other explar }\end{array}$ & $\begin{array}{l}\text { Binary variable, equal to } 1 \text { if sources of information stemming from } \\
\text { suppliers, clients or customers, competitors, or other firms in the same } \\
\text { sector are crucial for the firm's innovation activities, } 0 \text { otherwise. } \\
\text { Binary variable, equal to } 1 \text { if sources of information stemming from } \\
\text { conferences, meetings, and other such sources are crucial for the firm's } \\
\text { innovation activities, } 0 \text { otherwise. } \\
\text { atory variables }\end{array}$ & 0.163 & 0.370 \\
\hline $\begin{array}{l}\text { R\&D } \\
\text { intensity } \\
\text { Demand } \\
\text { pull } \\
\text { Cost push }\end{array}$ & $\begin{array}{l}\text { Sum of expenditures for intramural (in-house) R\&D and extramural } \\
\text { R\&D in } 2008 \text { divided by the total turnover in } 2008 \\
\text { Binary variable, equal to } 1 \text { if the innovation's objectives, such as } \\
\text { improved flexibility, increased capacity of production, reduced labour } \\
\text { costs, materials, or energy, are crucial for the firm, } 0 \text { otherwise. } \\
\text { Binary variable, equal to } 1 \text { if the innovation's objectives, such as } \\
\text { increased range of products, increased market share, or improved quality } \\
\text { of products, are crucial for the firm, } 0 \text { otherwise. } \\
\text { ector }\end{array}$ & 0.874 & 0.332 \\
\hline $\begin{array}{l}\text { Firm size } \\
\text { Group } \\
\text { Sectors } \\
\text { High } \\
\text { Med high } \\
\text { Medlow } \\
\text { Low }\end{array}$ & $\begin{array}{l}\text { High-tech manufacturing } \\
\text { Medium high-tech manufacturing } \\
\text { Medium low-tech manufacturing } \\
\text { Low-tech manufacturing (reference) }\end{array}$ & $\begin{array}{l}4.945 \\
0.713 \\
0.103 \\
0.270 \\
0.299 \\
0.328\end{array}$ & $\begin{array}{l}1.341 \\
0.452 \\
0.303 \\
0.444 \\
0.458 \\
0.470\end{array}$ \\
\hline
\end{tabular}


Appendix B. Results of the multivariate probit model for organizational practices

\begin{tabular}{llll}
\hline \hline Variables & Business practices & Workplace organization & External relations \\
\hline R\&D intensity & $-0.353(0.491)$ & $-0.671(0.600)$ & $-0.846(1.028)$ \\
Internal sources & $-0.111(0.071)$ & $-0.017(0.083)$ & $0.014(0.120)$ \\
Market sources & $0.166^{* *}(0.068)$ & $0.026(0.080)$ & $0.227^{* *}(0.114)$ \\
Institutional sources & $0.142(0.151)$ & $-0.302(0.228)$ & $0.307(0.221)$ \\
Other sources & $0.003(0.091)$ & $0.126(0.103)$ & $-0.038(0.153)$ \\
Firm size & $0.029(0.029)$ & $-0.012(0.035)$ & $-0.034(0.049)$ \\
Group & $-0.030(0.085)$ & $-0.199 * *(0.096)$ & $0.067(0.143)$ \\
High-tech & $-0.041(0.089)$ & $-0.033(0.148)$ & $-0.082(0.233)$ \\
Med-high & $0.002(0.084)$ & $-0.101(0.099)$ & $0.114(0.145)$ \\
Medlow & $-1.400^{* * *(0.140)}$ & $-1.329 * * *(0.164)$ & $0.070(0.143)$ \\
Intercept & 101.34 & & $-2.077^{* * *}(0.239)$ \\
\hline Wald $\chi^{2}(48)$ & -1435.54 & & \\
Log likelihood & & & \\
\hline \hline
\end{tabular}

Notes: Number of observations $=2673$. The $p$-values are in parentheses.

$*$,**, and *** denote significance at $10 \%, 5 \%$, and $1 \%$ levels, respectively.

Appendix C. Unconditional binary correlations between organizational practices

\begin{tabular}{llll}
\hline \hline & $\begin{array}{l}\text { Business } \\
\text { practices }\end{array}$ & $\begin{array}{l}\text { Workplace } \\
\text { organization }\end{array}$ & $\begin{array}{l}\text { External } \\
\text { relations }\end{array}$ \\
\hline Business practices & 1 & & \\
Workplace organization & 0.630 & 1 & 1 \\
External relations & 0.439 & 0.492 & \\
\hline \hline
\end{tabular}

